\title{
The use of interactional metadiscourse features to present a textual voice: A case study of undergraduate writing in two departments at the University of Botswana
}

\begin{tabular}{|c|c|}
\hline \multicolumn{2}{|c|}{$\begin{array}{l}\text { Author: } \\
\text { Boitumelo T. Ramoroka }{ }^{1}\end{array}$} \\
\hline \multicolumn{2}{|c|}{$\begin{array}{l}\text { Affiliation: } \\
\text { 'Department of } \\
\text { Communication and Study } \\
\text { Skills, University of Botswana, } \\
\text { Botswana }\end{array}$} \\
\hline \multicolumn{2}{|c|}{$\begin{array}{l}\text { Corresponding author: } \\
\text { Boitumelo Ramoroka, } \\
\text { ramorokab@mopipi.ub.bw }\end{array}$} \\
\hline \multicolumn{2}{|c|}{$\begin{array}{l}\text { Received: } 28 \text { Jan. } 2017 \\
\text { Accepted: } 07 \text { Mar. } 2017 \\
\text { Published: } 17 \text { May } 2017\end{array}$} \\
\hline \multicolumn{2}{|c|}{$\begin{array}{l}\text { How to cite this article: } \\
\text { Ramoroka, B.T., 2017, } \\
\text { 'The use of interactional } \\
\text { metadiscourse features to } \\
\text { present a textual voice: A } \\
\text { case study of undergraduate } \\
\text { writing in two departments } \\
\text { at the University of } \\
\text { Botswana', Reading \& Writing } \\
\text { 8(1), a128. https://doi. } \\
\text { org/10.4102/rw.v8i1.128 }\end{array}$} \\
\hline \multicolumn{2}{|c|}{$\begin{array}{l}\text { Copyright: } \\
\text { (c) 2017. The Authors. } \\
\text { Licensee: AOSIS. This } \\
\text { is licensed under the } \\
\text { Creative Commons } \\
\text { Attribution License. }\end{array}$} \\
\hline \multicolumn{2}{|l|}{ Read online: } \\
\hline 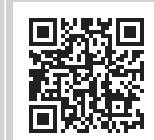 & $\begin{array}{l}\text { Scan this QR } \\
\text { code with your } \\
\text { smart phone or } \\
\text { mobile device } \\
\text { to read online. }\end{array}$ \\
\hline
\end{tabular}

\begin{abstract}
In recent years, there has been an increased emphasis on the interpersonal function of metadiscourse features in academic texts. This means that research on writing in academic contexts began to focus on the rhetorical features, such as interactional metadiscourse, that writers use to present their voice in writing. These developments in academic writing have also considered the context in which specific genres are produced. Using a multiplemethods approach to genre analysis, this article compares students' use of interactional metadiscourse features in two undergraduate courses, Media Studies and Primary Education at the University of Botswana. A total of 40 student essays were analysed. Interviews with students and lecturers in the two departments were also done to understand the context in which the essays were produced. The comparison of interactional metadiscourse features in the two corpora indicated that interactional metadiscourse markers were present, but that there were variations in the use and distribution of these features by the learners. Contextual information shows that such variations reflect the different values and beliefs about academic writing of the discourse communities that students belong to. These values and beliefs can be problematic for English for Specific Purposes (EAP) lecturers who have to prepare students for writing in the various disciplines in $\mathrm{L} 2$ contexts.
\end{abstract}

\section{Introduction}

Over the last two decades, there has been a shift in the way academic writing is perceived based on the view that writing is a social and communicative engagement between the writer and the reader and that writing is not entirely voiceless and impersonal (Hyland 2005; Ivanic 1998; Ivanic \& Camps 2001; Ivanic \& Simpson 1992; Lillis 1997; Sheldon 2009). Ivanic and Camps (2001:5) argue that 'there is no such thing as "impersonal" writing' because writers express messages about themselves through different acts and through a range of resources that are culturally available to them.

As a result of this view, there has been an increasing interest in the study of metadiscourse as a tool which can be used to explore the interactive nature of texts. Hyland (2005a) developed a framework for analysing interactions in written texts. This framework is a metadiscourse model which builds on earlier models of metadiscourse particularly Thompson and Thetela's model (1995) and Vande Kopple's model (1985). Metadiscourse addresses the notion that academic writing is more than communication of propositional content, but it also involves how the writers project their personality and attitudes towards the proposition. Hyland (2005a:37) defines metadiscourse as a 'cover term for the self-reflective expressions used to negotiate interactional meanings in a text, assisting the writer (or speaker) to express a viewpoint and engage with readers as members of a particular community'.

Hyland's framework tends to draw insights from the systemic functional description of language which sees language use as performing three macro-functions (Hyland 2005a; Vande Kopple 1985). Halliday (1994) calls these the ideational, interpersonal and textual functions. The ideational function is concerned with the 'propositional content'; the textual function is concerned with how language is used to organise the text and the interpersonal function is concerned with 'use of language to encode interaction, allowing us to engage with others, to take on roles and to express and understand evaluation and feelings' (Hyland 2005a:26). 
Hyland's proposed framework consists of two dimensions of interaction; the interactive and the interactional dimensions. The interactive resources help the writer to organise propositional content to make it coherent. These features are transition markers, frame markers, endophoric markers, code glosses and evidential. Interactional resources allow the writer to intrude and comment on their message. Hyland calls this 'writer's expression of a textual "voice"' (Hyland 2005a:49). The resources that allow for this are self-mention, hedges, boosters, attitude markers and engagement markers. The interactional resources involve the reader in the argument and indicate the writer's perspective towards the propositional content (Hyland 2004). Hyland develops Halliday's idea of tenor in that he relates it to the notion of writer voice and writer positioning. Hyland (2004:168) points out that interactional resources relate to the tenor of the discourse, concerned with controlling the level of personality in a text'.

Self-mention 'refers to the degree of explicit author presence in the text' (Hyland 2005a:53). This can be realised by the use of first person pronouns and the possessive adjectives 'I, me, my, our, mine and us'. Other features that can be used to 'selfmention' are 'the author, the writer, the author's and the writer's'. Hedges are resources that writers use 'to recognize alternative voices and viewpoints and so withhold commitment to the proposition' (Hyland 2005a:52). According to Hyland, hedges allow the writer to present information as an opinion or a plausible reasoning rather than a fact. Examples of hedges are 'in my view, in my opinion, likely and tend'. Other resources available are boosters. Unlike hedges, boosters help writers to express with certainty what they have to say. Examples are 'indeed, certainly and defiantly'. Engagement markers are used by writers to explicitly address the readers and engage them in the dialogue. This can be performed by the use of inclusive 'we, our and us', reader pronouns 'you and your' and the question mark. Hyland (2005a:365) points out that the most obvious indication of a writer's dialogic awareness occurs when he or she overtly refers to readers, asking questions, making suggestions and addressing them directly'. The last interactional resources are attitude markers. Hyland (2005a:53) points out that they 'indicate the writer's affective, rather than epistemic, attitude to proposition'. Examples are 'unfortunately, interestingly and fortunately'.

\section{Literature review}

Metadiscourse has been recognised as one of the important features and strategies that can be used by writers in the production of written texts. Hyland (2005a) also posits that metadiscourse is:

a key dimension of genre analysis as it can help show how language choices reflect the different purposes of writers, the different assumptions they make about their audiences, and the different kinds of interactions they create with their readers. (p. 88).

Camiciottoli (2003:29) points out that 'metadiscourse allows written texts to take on some features of spoken language (e.g. personal pronouns to establish an "I-you" relationship) and thus become more "reader friendly"'. Hyland (2005a:178) outlines some possible contributions that metadiscourse can make to a text. Some of these are:

- It provides a context in which to place propositional information.

- It injects a human presence into a written text and so makes students more attentive and engaged with a text.

- It increases the persuasiveness of a text.

- It highlights writer uncertainties and makes readers aware of the subjective interpretation of truth.

- It helps show the author's position on the propositional information in a text.

- It shows readers that the writer recognises their needs and is seeking to engage them in a dialogue.

Therefore, researchers have taken interest in studying the use of metadiscourse features in both undergraduate writing and post graduate writing and how it varies across disciplines. Some comparative studies of students' writing in different contexts have also been performed.

Some studies on the use of interpersonal metadiscourse features in academic context examined disciplinary variation in the use of metadiscourse features (Abdi 2002; Hyland 2004) and these studies focused on the research genre. For example, Abdi (2002) examined the way researchers use interpersonal metadiscourse to reveal their identity. Abdi analysed 60 academic research articles in the fields of social sciences (SS) and the natural sciences (NS), and the study was confined to discussion sections because it is the part where writers most obviously try to persuade their readers. In this study, there were significant differences in the use of hedges and attitude markers by the two groups, with the natural science writers displaying more certainty about their proposition. His argument is that because natural science writers report empirical research and are objective in their reporting, some of the uncertainties are removed. Social science writers, on the contrary, tended to intervene a lot (through the use of interpersonal metadiscourse features) and were subjective in their reporting of the proposition. Abdi's findings suggested that the choice of interpersonal metadiscourse was discipline related.

Another study that yielded similar findings was conducted by Hyland (2004). The study focused on how L2 postgraduate students used both interactive and interactional metadiscourse, and this was based on an analysis of 240 L2 postgraduate dissertations for both master's and doctoral students. His analysis indicates the significance of metadiscourse in academic writing, particularly this genre. The results show that the writers used slightly more interactive than interactional (interpersonal) metadiscourse features. There was also significant difference in the use of metadiscourse across the disciplines, with the humanities and social sciences employing more metadiscourse and over $60 \%$ of the interactional features. The interactive metadiscourse was balanced across the disciplines and 
formed a higher proportion of use of metadiscourse in the science dissertations.

Some studies looked at variation in the use of metadiscourse across different languages and cultures. One such study was conducted by Crismore, Markkanen and Steffensen (1993). They conducted a comparative study of use of metadiscourse of texts written by American and Finnish university students. The participants were mature writers who were in upper level of undergraduate studies or graduate students. The purpose of the study was to investigate cultural variation in the use of metadiscourse by these two groups. For the purposes of their study, they did not use the standard genre that students would usually write but rather chose a 'controversial' topic which would be of interest to the students but also appropriate for university students in the two contexts. Multiple raters were used to ensure that coding was consistent. A significant finding of this research was that students in both contexts used all categories and subcategories of metadiscourse the researchers had identified indicating the universality of metadiscourse. The findings indicated that there were some cultural differences in the amounts of metadiscourse used. For instance, the data indicated that the Finnish students used more hedges, about five times more than the American students, and more attitude markers than the American students, whereas the American students expressed certainty and attributed ideas to sources more often than the Finnish students. The study reports that students in both countries used more interpersonal metadiscourse than textual metadiscourse. Abdi (2002) argues that the use of interpersonal metadiscourse is an indicator of the attempt made by the writer to reach their audience. He argues that 'the more interpersonal the nature of the metadiscourse markers used in a text, the more the writer of the text intends to achieve these goals' (Abdi 2002:142).

In addition, there are some studies which investigate the use of metadiscourse by undergraduate students. One such study which seemed to suggest that metadiscourse can be an important feature of good English as a Second Language (ESL) and L1 writing was done by Intaraprawat and Steffensen (1995). In their study, Intaraprawat and Steffensen analysed the use of metadiscourse in L2 persuasive essays written by English as second language university students. Half of the essays had received good ratings and the other half had received poor ratings. The good essays showed greater variety in the use of metadiscourse and more metadiscourse than poor essays. Good essays had a higher percentage of interpersonal metadiscourse, whereas poor essays had a higher percentage of interactive metadiscourse features. They concluded that 'metadiscourse is a facet of written text that varies with overall quality of the essays. Better essays include a wider range of forms and more of them' (Intaraprawat \& Steffensen 1995:268).

In another study, Cheng and Steffensen (1996) adopted a different methodological approach to the study of metadiscourse. They carried out an experimental study to determine the effects of students' awareness of metadiscourse on their own writing abilities. They conducted a 16-week experiment in which one part of an L1 university class was exposed to metadiscourse features as part of composition writing while the other part of the class was not. Pre- and post-test papers were analysed to determine whether metadiscourse usage was different in the two groups. The results indicated that the group that was exposed to metadiscourse benefited from instruction about metadiscourse as they scored significantly higher scores compared to the control group and used metadiscourse skilfully. The study seems to suggest that teaching students the use of metadiscourse was crucial in helping them to improve their writing. In fact, Hyland (2005) argues that metadiscourse can facilitate communication and increases the readability of a text and builds relationship between the writer and the reader.

A more recent study was conducted by Letsoela (2013) who examined the use of metadiscourse features by undergraduate students at the University of Lesotho. Her study looked at how students used both interactive and interactional metadiscourse features in the discussion section of their final year research project. The results of her study revealed heavy use of interactive metadiscourse rather than interactional metadiscourse. Students generally avoided the use of selfmentions and engagement markers. Her study seemed to suggest that students were more concerned about producing coherent texts than to explicitly intrude into their texts.

\section{Justification for this study}

Despite the contribution of the studies reviewed above to the area of metadiscourse, more studies are required to gain more in-depth understanding of how students use metadiscourse in different contexts like the University of Botswana and within the same discipline. Furthermore, most of studies on metadiscourse carried out tend to focus on identifying and quantifying instances of metadiscourse features, and on interpreting the functions of these features. Most of these studies also tend to focus on comparing how writers use both interactive metadiscourse, where the writer seeks to guide the reader through the text, and interactional metadiscourse features, where the writer expresses a stance towards the proposition, in their writing. There seems to be little attention paid to understanding the context in which the texts were produced. This study seeks to address this gap in the existing literature by carrying a comparative study of the use of interactional metadiscourse within two courses that are both in the humanities at the University of Botswana. Furthermore, the study also includes interviews with insiders, which are both students' and lecturers' under which the writing was produced in order to understand how they perceive and respond to the use of interactional metadiscourse and what factors influence students' choices.

Drawing also from my experience of the teaching of the writing module in the English for Specific Purposes (EAP) 
course at the University of Botswana, a lot of attention and emphasis in the teaching of essay writing skills is usually on the interactive metadiscourse features that help writers to organise propositional information such as transition markers. Metadiscourse features, which have an interpersonal function, are rarely taught in the EAP course. Thompson suggests that the reason for this bias in teaching could be that 'interactional signals are typically less frequent and less overt in academic text' (2001:73).

Accordingly, this article presents a small corpus based study of the use of interactional metadiscourse features by students in two different departments, Media Studies and Primary Education, at the University of Botswana. A comparison of students' writing in the two departments will be done in order to see how each group used interactional resources in their writing to present. The overarching objective of the study is to look at how the students use interactional metadiscourse features to present a textual voice. The study attempts to answer the following research questions: (1) Are there any differences in the use of interactional metadiscourse features between the writing produced by Media Studies and Primary Education undergraduate writers in this study? (2) Are there any patterns about where in the text interactional metadiscourse features occur more frequently? For instance, can we find evidence that certain features are more frequent either in the introduction, body or conclusion of the essay and does this vary by corpus; (3) What factors influenced the choice of interactional metadiscourse features by the students in both Media Studies and Primary Education in this study?

\section{Developing a model of analysis}

The analytical framework for the study of interactional metadiscourse has been shaped by different typologies. This paper uses Tang and John's (1999) taxonomy of first person pronouns which suggest that the degree of author explicitness in the text depends on the role that the writer has adopted. It has also been shaped by a taxonomy proposed by Hyland (2005a) for the analysis of interactional metadiscourse features. Hyland (2005a:58) makes it clear that 'no taxonomy or description will ever be able to do more than partially represent a fuzzy reality'. This is because the taxonomies provide explicit surface features which can be identified in a text. What a classification like this can do is to 'only approximate the complexity of natural language use' (Hyland 2005a:59). This means that in the identification and classification of metadiscourse items, we cannot rely only on overt surface features but equally importantly we can also draw on multiple factors which might help us capture the writer's intentions. We cannot regard textual features as ends in themselves.

Metadiscourse is also a functional category and can be realised in a variety of linguistic features (Adel 2006). Some features are sometimes used to perform different functions and as such there are inevitable overlaps which make the categorisation of metadiscourse challenging. Hyland (2005a) also points out that metadiscourse items may play different functions in different texts or can at times be used to perform two functions at the same time. This multi functionality of metadiscourse features means that 'metadiscourse cannot be regarded as a strictly linguistic phenomenon at all, but must be seen as a rhetorical and pragmatic one' (Adel 2006:27).

Although Hyland's model provides a useful starting point for the analysis of interactional metadiscourse features by providing a list of items that can potentially function as metadiscourse features, I approached the texts with an open mind to see what other language features I might find that are not listed in Hyland's framework. Therefore, for the identification of potential features that perform a metadiscoursal function, sometimes I had to move beyond looking at the explicit textual features to work with the textual context in order to justify that a particular feature performs a particular metadiscoursal function other than the one specified in the taxonomy. The identification and labelling of metadiscourse features was based on the cotextual effects or impression the writer creates as he or she writes. Adel (2006:25) emphasises the importance of context in labelling items by pointing out that 'although some forms are basically inherently metalinguistic, we still cannot classify a linguistic form as metadiscourse without taking the context of each particular instance into consideration'.

\section{The study}

\section{The context}

The study was undertaken in two departments at the University of Botswana, the Department of Media Studies which is in the Faculty of Humanities, and the Department of Primary Education which is in the Faculty of Education. The Department of Media Studies offers the Bachelor in Media Studies (BMS) degree. The program introduces students to the world of electronic and print journalism. It opens career opportunities in journalism, both print and electronic as well as script writing, advertising and public relations. Media education students do a lot of writing right from the first year as they train to become journalists.

The Department of Primary Education runs in-service programmes for teachers who have been in the field for some time and who have had training up to the diploma level. The students in this department are mature students who have a lot of work experience as teachers. The department offers a Bachelor's Degree in Education (BEd Primary). It also offers a Bachelor of Educational Management programme for improving educational management.

Within the University of Botswana context, all new students do a compulsory Academic Literacy course in their first year. The course is in two parts, the first part is an introduction to communication, reading, speaking and listening and generic writing skills. The second component of the course introduces students to what are considered discipline specific writing skills demands. Lecturers concentrate on text types like 
exposition, description, narration and argumentation. Therefore, students in this study went through this course in their first year and were now in their third year.

The choice of these two departments (Primary Education and Media Studies) was based on the fact that students in these departments do a lot of writing. The students in both departments are assessed on similar kinds of learning outcomes where they have to organise knowledge learnt and be able to articulate their arguments clearly in writing. I selected texts that were classified under the same genre family of 'the essay' where the communicative purpose of the essay was to present arguments for and against an issue in order to convince the reader of a particular point of view.

\section{Method}

\section{Corpus}

The study is based on a small corpus consisting of 40 essays written by undergraduate students from the University of Botswana. Table 1 below shows the size of the corpus.

The students were selected through convenience sampling and the researcher did not, in any way, consider selecting a sample that was representative of the entire population. Only students who were willing to participate in the study submitted their essays and completed a consent form. The essays students wrote were part of the regular assessment requirements and students were given a writing task which required them to write an academic essay of about 1200 words to 1500 words as homework (see Appendix 1). Students were required to do research and cite sources and make a convincing argument. Students who consented to participate provided handwritten copies of their course assignment. These were transcribed and saved in text format.

\section{Interview data}

Interviews were conducted with six students (three students in each department) and six lecturers (three lecturers in each department) in the two departments. The interviews were transcribed and analysed. The interview guide solicited information on how students interacted with their readers and whether they were aware of their audience. Therefore, the questions prompted both students and lecturers to elaborate on the features students use to interact with their readers and whether students were encouraged to use first person pronouns in their writing.

TABLE 1: Showing the data used and size of the corpora.

\begin{tabular}{lcc}
\hline L2 undergraduate writing & Corpus size in words & Number of texts \\
\hline Media Studies texts & 33825 & 20 \\
Primary Education texts & 36572 & 20 \\
\hline
\end{tabular}

\section{Analysis of the data}

Both quantitative and qualitative analysis of interactional metadiscourse features were carried out. A manual frequency count of interactional metadiscourse features was done. In a small number of cases where features performed more than one metadiscourse function, both functions were counted, reflecting the analytical procedure used by Intaraprawat and Steffesen (1995) in metadiscourse analysis.

In order to validate the results that I got from the initial analysis of metadiscourse features, an electronic search of these features was done using Wordsmith Tools 5 (Scott 2008) to analyse the essays. Using the Concord tool, I did a reverse check, where I started with a list of features I identified in the initial analysis, Hyland's (2005a) published list of interactional metadiscourse items investigated in his study, and Mur Duenas (2010) published list of attitude markers as a starting point for this analysis. Once I had identified features that were considered interactional metadiscourse features, the corresponding features were searched for using the Wordsmith Tools 5 Concord tool. The concordance provides a list of all occurrences of the search words in a corpus together with the context in which they occur. Both the manual analysis and the computer assisted search complemented each other.

The results from the Wordsmith programme provide statistical information, such as how many instances a particular feature appears in the whole corpus (raw frequency) and the frequency of use of each feature per 1000 words (mean). To determine whether the differences in use of interactional metadiscourse features by the different groups were statistically significant, t-tests were performed to compare the means of the different features.

\section{Results and discussion}

\section{Comparison of use of interactional metadiscourse features by Media Studies and Primary Education students}

The first research question sought to find out whether there were any differences in the use of interactional metadiscourse features between the writing produced by Media Studies and Primary Education undergraduate writers in this study. The table below gives a summary of the results for the two corpora being compared here. The results reveal observable differences across the two corpora. As the Table 2 indicates, students in both departments used all categories of interactional metadiscourse features.

A comparison of the two corpora shows a higher incidence of occurrences of interactional metadiscourse features in Media

TABLE 2: Frequency distribution of interactional metadiscourse features for Media Studies and Primary Education writing per 1000 words.

\begin{tabular}{|c|c|c|c|c|c|c|c|c|c|c|}
\hline \multirow[t]{2}{*}{ Metadiscourse } & \multicolumn{2}{|c|}{ Self-mention } & \multicolumn{2}{|c|}{ Hedges } & \multicolumn{2}{|c|}{ Boosters } & \multicolumn{2}{|c|}{ Attitude markers } & \multicolumn{2}{|c|}{ Engagement markers } \\
\hline & $n$ & $f / 1000$ & $n$ & $f / 1000$ & $n$ & $f / 1000$ & $n$ & $f / 1000$ & $n$ & $f / 1000$ \\
\hline Primary Education & 29 & 0.78 & 32 & 0.86 & 16 & 0.45 & 2 & 0.06 & 9 & 0.24 \\
\hline Media Studies & 40 & 1.18 & 49 & 1.45 & 36 & 1.33 & 9 & 0.27 & 14 & 0.42 \\
\hline
\end{tabular}


Studies essays compared to Primary Education essays. For instance, the results indicate that Media Studies students used slightly more self-mention than Primary Education students. A similar pattern emerges with the use of hedges, boosters, attitude markers and engagement markers, with Media Studies students using notably more interactional metadiscourse features than Primary Education students. However, the t-tests for independent samples results showed no significant differences in the use of these features in the two corpora.

The second research question sought to find out whether were any patterns about where in the text interactional metadiscourse features occur more frequently. For instance, can we find evidence that certain features are more frequent either in the introduction, body or conclusion of the essay and does this vary by corpus? To answer this question, I will look at how students used each of the international metadiscourse features.

\section{Use of self-mention}

A look at usage of self-mention in both Media Studies and Primary Education essays shows that students do use first person pronouns though in small numbers. The first person pronoun 'I' was the most common author reference in Media Studies essays, with 39 instances of the use of this pronoun and only 1 instance where the writer used another form of self-mention.

The use of self-mention by Media Studies students was prevalent in the introductory section of the essays and students used the first person pronoun more frequently in conjunction with the least powerful functions of 'I as the guide of the essay' and 'I as the architect of the essay', where students showed the structure of the essay or indicated commitment to the proposition. A typical example is seen below.

\section{Example 1:}

'Firstly, I will focus on discussing women as a social group, paying particular attention on how they are or have been represented in media' (BMS 302-3; student in Media Studies [author's own emphases]).

I found 14 instances where students did not make explicit reference to themselves as agents of their work yet they were still present in their work. This occurred frequently in the introduction to signpost or to provide an overall structure of the essay. The extracts below exemplify this use.

\section{Example 2:}

'Secondly, this essay will discuss whether or not it is possible to receive unbiased news because of ownership of various media. Thirdly, this paper will touch on how globalisation of mass media affects the average citizen' (BMS 302-11; student in Media Studies [author's own emphases]).

\section{Example 3:}

'The argument first gives a brief analysis of functions of art in an African society. It will then explore ways in which the artistic value is diminished or enhanced if used for purposes other than the intended function' (BMS 410-11; student in Media Studies [author's own emphases]).

The table indicates 29 instances of use of self-mention in the Primary Education corpus. Although students explicitly used the first person pronoun ' $\mathrm{I}$ ', they also tended to use other forms of self-mention such as the writer and the researcher. This seemed to be a common feature of this corpus. The extracts below show examples of how the students used these in their essays.

\section{Example 4:}

'By the above citation the researcher believes that if pupils are aware of the above description of a good citizen' (EPS 200-3; student in Primary Education [author's own emphases]).

Example 5:

'The writer (of the essay) was convinced that the national principles played an important role in this regard' (EPS 200-1; student in Primary Education [author's own emphases]).

The other form of self-mention which was used in this corpus was the use of the first person plural 'we' which was used to exclude the readers from the text. There were three instances of the use of the exclusive pronoun 'we' in this corpus and these came from the same essay. Extract 6 below comes from the introductory paragraph.

\section{Example 6:}

'In this argument, we shall indicate how the environmental challenges caused by these activities' (EPI 442-13; student in Primary Education [author's own emphases]).

It is interesting that the use of other forms of author reference phrases like 'the writer', 'the author' or 'the researcher' and the exclusive 'we' occurred in Primary Education essays while essays for Media Studies explicitly used the first person pronoun 'I' as author reference. As Adel (2006:86) observed, 'this strategy is probably used to increase the objectivity and "detachment" of the writer of the text'. Adel (2006:86) also suggests that 'one reason for writers to refer to themselves in the third person is that it gives a formal impression' (p. 86).

The use of first person pronouns in the argument stage of the essays were comparatively low in both corpora. Students used the first person pronoun to guide the reader through the text where they made a claim and supported it with evidence, or introduce a countermove, or refer to a proposition made earlier.

\section{Example 7:}

'I believe 'othering' is the reason for conflict in the world' (BMS 401-1; student in Media Studies [author's own emphases]).

The findings about the use of first person pronouns is in congruent with what Hyland (2002) and Tang and John (1999) observed that many L2 writers not only chose to avoid 
self-mention, but principally chose to avoid it at points where it involved making a commitment to an interpretation or claim. They generally sought to 'downplay their authorial identity by restricting their visibility to the more innocuous functions, such as guiding readers through the discourse' (Hyland 2002:1106). Martinez (2005:175) also observed that students used the first person pronoun in 'non-controversial contributions, such as stating discourse goals ...'

Tang and John (1999) also argue that students can be intimidated by using the first person pronoun to originate ideas and opinions because it would appear that they are:

aligning themselves with textbook writers and lecturers in terms of their right to be 'authors'... students feel insecure about the validity of their claims, seeing themselves to be at the lowest rungs of the academic ladder. (p. S34).

This also tends to support a previous study performed by Read, Francis and Robson (2001) that students lack the confidence to present their voice 'as they feel they are not able to challenge the opinions of "established" academics' (p. 394).

\section{Use of engagement markers}

Both Media and Primary Education Students used engagement markers less frequently in their essays. The use of the inclusive pronoun ' $\mathrm{we}^{\prime}$ and rhetorical questions were common. Students' use of these features indicated that they were aware of the need to engage in some sort of dialogue with their readers. Inclusive pronouns help the writer construct dialogism between themselves and the audience by establishing the presence of the readership in the text, and making the discourse reciprocal' (Harwood 2005:347). The rhetorical questions also add a dialogic element to students' writing, with the following as an example.

Example 8:

'The museum has an influential role to play in the society. How does it use the components of various ethnic groups to define the national heritage? This has to be performed by making sure that various ethnic groups are represented' (BMS 401-11; student in Media Studies [author's own emphases]).

The writers anticipated the reactions of the readers and they continued to address them. The use of rhetorical questions was common in the argument stage of the essays.

In the two examples below, the writers draw the reader into the text by using the inclusive pronoun ' $w e^{\prime}$ ' so that the reader may be persuaded to see the writer's viewpoint.

Example 9:

'Firstly, we must look at the definition in context' (BMS 302-12; student in Media Studies [author's own emphases]).

\section{Example 10:}

'In a nutshell, we can conclude that women in the media are portrayed in a stereotypical, often sexist and usually impossible way' (BMS302-3; student in Media Studies [author's own emphases]).

\section{Use of hedges, boosters and attitude markers}

The use of hedges was common in the argument stage in both corpora where students hedged their claims.

Example 11 below typifies the above mentioned:

'Because of these perceptions of viewing certain foreigners 'traditions as ungood or weird, Batswana tend to distance themselves from them.' (BMS 401-10; student in Media Studies [author's own emphases]).

Media Studies students tended to use more hedges than Primary Education students.

I counted 16 instances of boosters in Primary Education corpus and 36 instances in Media Studies corpus and these appeared in the argument and conclusion stages of the essays and students tended to use these to express certainty, show conviction and belief about a certain point they were making. Attitude markers were very uncommon in these corpora with only two instances of use of attitude markers in Primary Education corpus and nine instances in the Media Studies corpus.

\section{Perspectives from the lecturers and students}

The third research question sought to find out factors that influenced the choice of interactional metadiscourse features by the students in both Media Studies and Primary Education in this study.

To do that, I conducted interviews with students and lecturers in both departments of Primary Education and Media Studies for the courses in which these writings were produced. The interviews were exploratory in nature and focused on how students interacted with their readers and whether they were aware of their audience and whether students were aware of the language features they could use to interact with their readers. I was also interested in finding out whether students were encouraged to use first person pronouns in their writing.

I asked for the views of the participants about the issue of audience in students' writing. I focused on whether students' writing has an audience and what kind of audience it was. Students in both departments pointed out that their audience was their lecturer who reads and marks their work. The lecturers also felt that in most cases students write for them. A follow up question on whether students were able to interact with their audience was asked. One lecturer in the Department of Primary Education felt that students were not able to engage in a dialogue with their readers because of their level. His comment was:

'I don't see that at this level (meaning that they are undergraduates) because if you write an academic paper for instance in the literature review that is what I try to do....but in students' writing you seldom see that kind of writing because of their level.' [lecturer in Prımary Education] 
One lecturer in the Department of Media Studies perceived students' audience as twofold. The lecturer made a distinction between academic writing and professional writing. According to him, when students engage in professional writing, they have an audience they are targeting. He pointed out that when students are clear about who their audience is their writing becomes very interactive. However, the three Media Studies lecturers emphasised the need for the writer to interact with the readers as something they would value in writing.

Lecturers were asked for their views concerning the use of personal pronouns in academic writing because some students had used these in their writing. Primary Education interviewees held different views about the use of personal pronouns in students' writing. For instance, one participant commented that:

somewhere we had a debate on that issue and some people were saying there is nothing wrong with using first person. That was within this department. People hold different views.' [lecturer in Primary Education]

He, however, does not discourage students from using first person pronouns because they have to state what they feel in the first person if it is a question that requires them to state their point of view.

The other two participants' in the Department of Primary Education responses suggested largely that the use of the first person pronoun ' $I$ ' was unacceptable in academic writing. Responses like, 'that it is not academic', 'it is not allowed', and 'it is not professional' came out. One of the two participants argued that:

'...yes they have personal opinions on some of those things but really at the level where we are now, they cannot say those things with authority. I have always encouraged them to say, "one would"...' [lecturer in Primary Education]

He says writing this way takes the "blunt personal thing out" and therefore is acceptable in academic writing.

This was similarly the case with participants from Department of Media Studies. One participant pointed out that:

'...there is some variety within the department. We have had debates within the department and there are some people who feel very strongly that the "I" should be removed... I don't feel that.' [lecturer in media studies]

The other participant suggested that instead of writing:

'I believe media in Botswana is very racist', [lecturer in Medıa Studies]

she would prefer that the students write: 'media in Botswana seems to be portraying this as...'

She raised an interesting comparison by drawing on her own experiences of academic writing. She argued that: 'it is the kind of thing I do for my academic papers, where there is some level of

detachment...' [lecturer in Medıa Studies]

This view was also reported by students in the interviews. One of the students from the Department of Primary Education said this:

'but when it's a general essay I don't have to use "I think that..." I can say "one may think that..."' [student in Primary Education]

Another informant also from the same department commented that:

'you will talk about "the researcher did this..." "We don't use the "I".' [student in Primary Education]

Students were quite rigid about this view in their responses and were adamant that it was an appropriate practice of essay writing.

However, another lecturer in Media Studies was concerned that some students were very distant from their writing. He gave this illustration to emphasise how a writer can interact with the reader, 'This essay is about this and when writing this essay I will do this and that...' He argues that this would help the writers to launch the readers into their writing. He also pointed out that he wants his students 'to associate with their work' and not say 'the researcher' or the 'writer'. He further mentioned that he values an essay that has 'character'. He said that this is where the writer not simply narrates incidents from a distance but is walking with the reader so that the reader can see the writer in the text'.

Furthermore, I asked both the lecturers and the students to elaborate on other language features apart from first person pronouns they can use to interact with the audience. Generally, their response seemed to indicate that they were not aware of language features writers could use to interact with their audience.

\section{Summary of results and pedagogical implications}

The limitations of this study need to be considered when discussing these findings. Firstly, the corpus for this study was very small and it is not representative of the entire population in these two departments. Secondly, my study did not focus on the relationship between the use of interactional metadiscourse and the quality of writing. I believe such information could have proved useful.

In spite of the limitations mentioned above, I believe that this study provides useful starting point to understand how students at the University of Botswana use interactional metadiscourse in their writing to interact with their audience and present a textual voice. Overall, this study indicates that students at the University of Botswana do use metadiscourse in their writing to interact with their audience and engage them in a dialogue. However, the results indicate that 
students had a narrow repertoire of interactional resources to use to present a textual voice.

The results contribute to support the view that interactional metadiscourse is a universal feature of academic writing (Crismore et al. 1993) and that academic writing is not completely impersonal (Hyland 2002). The study has also revealed how the two groups of students differ in their use of interactional metadiscourse features. The results seem to indicate that even within the same discipline, there can be variations on how students use interactional metadiscourse features. For instance, Media Studies students were far more explicitly involved in their writing, whereas Primary Education students seemed to hold back and distance themselves from their writing.

The interview data proved useful in highlighting the values, practices as well as lecturer's beliefs about students' writing and academic conventions. The findings seem to indicate that students' awareness to interact with their audience can be overridden by the disciplinary conventions, beliefs and values about academic writing as seen from the interviews with the expects' informants. For instance, the data indicated that lecturers held different and sometimes contradictory views with regard to the use of first person pronouns in academic writing. Students are largely dependent on their lecturers' for advice but there is seemingly conflicting advice given by lecturers on the use of the pronouns. This could possibly be some of the factors that influenced how students used interactional metadiscourse features in their writing, especially the use of personal pronouns.

Li and Wharton (2012) posit that local institutional culture could have a noticeable influence on student writers' use of metadiscourse. Hyland (2002) commenting on this argument expresses concern that:

conventions of identity are notoriously uncertain. On the one hand impersonality is seen as a defining feature of expository writing... and many textbooks and style guides advise students to avoid personal intervention... However other textbooks encourage writers to make their own voice clear through the first person. (p. 1095)

These conflicting views might be problematic for the EAP lecturers who have to prepare students for writing in the various disciplines because there seems to be no clear guidelines on the requirements of academic writing in the two departments. This means that students do what their individual lecturers perceive to be good practice.

Despite these conflicting views, the results of this study suggest pedagogical implications for the teaching of the preparatory EAP writing course at the University of Botswana. The analysis has helped to illuminate our understanding of how students use interactional metadiscourse features in their writing, and what influences their choices.

The findings can inform the design of the EAP writing course so that we incorporate the teaching of this in our EAP courses. Issues of audience, interaction and understanding the dialogic nature of academic writing, and presentation of voice in writing can be included in the EAP writing course. We notice that students used a limited range of linguistic resources to position themselves, to interact with the readers and to present their voice in writing. Students could therefore benefit more from explicit teaching about the different categories and functions of interactional metadiscourse features available. Hyland (2001) argues that:

academic writers have rhetorical options then, and the effects of manipulating these options suggest that there are considerable advantages for our students in being aware of them. The whole issue of consciousness-raising is crucial in EAP and is central to learning to write effectively. (p. 224)

For instance, depending on the rhetorical situation, students could decide whether to use interactional resources available to them to make explicit their perspective towards propositional information. Students could be made aware that the presentation of author voice is marked by linguistic features such as hedges, boosters, engagement markers, attitude markers and self-mention. Students could be made aware of the discourse functions of the first person pronoun and how students could use the first pronoun ' $\mathrm{I}$ ' (and at what point in the text) to make themselves visible as well as assert themselves into the text. Students could be made aware that texts are crafted out of other texts and that writers need to reflect both their voice and voices of those they have borrowed from and they need to be made aware of resources available to them to do so.

Although lecturers from the two departments held different views, particularly about the use of personal pronouns, this study proposes the inclusion of interactional dimension into the EAP writing course as students may benefit from their teaching. It is important to complement the teaching of interactive metadiscourse features with the teaching of interactional metadiscourse features and awareness of audience in writing. In the light of the results found, I would argue that issues regarding how much metadiscourse or writer and/or reader visibility to employ in writing are far from self-evident, but need more explicit attention in the ESL classroom' (Adel 2006:200).

\section{Conclusion}

This study extended the research on the study of interactional metadiscourse features by examining how students used these to present a textual voice. The study incorporated interviews with insiders to these two departments to see how they perceive the use of these features in academic writing. The results suggest that students' use of these features might be influenced by how their lecturers perceive the use of interactional metadiscourse features.

\section{Acknowledgements Competing interests}

The author declares that she has no financial or personal relationships which may have inappropriately influenced her in writing this article. 


\section{References}

Abdi, R., 2002, 'Interpersonal metadiscourse: An indicator of interaction and identity', Discourse Studies 4(2), 139-145. https://doi.org/10.1177/1461445602 0040020101

Adel, A., 2006, Metadiscourse in L1 and L2 English, John Benjamins Publishing Company, Amsterdam.

Camiciottoli, B.C., 2003, 'Metadiscourse and ESP reading comprehension: An exploratory study', Reading in a Foreign Language 15(1), 28-44.

Cheng, X. \& Steffenson, M., 1996, 'Metadiscourse: A technique for improving student writing', Research in the Teaching of English 30(2), 149-181.

Crismore, A., Markkanen, R. \& Steffensen, M.S., 1993, 'Metadiscourse in persuasive writing: A study of texts written by American and Finnish university students', Written Communication 10(1), 39-71. https://doi.org/10.1177/0741088 393010001002

Halliday, M.A., 1994, An introduction to functional grammar, Edward Arnold, London.

Harwood, N., 2005, 'We don't seem to have a theory', Applied Linguistics 26(3) 343-375. https://doi.org/10.1093/applin/ami012

Hyland, K., 2001, 'Humble servants of the discipline? Self mention in research articles', English for Specific Purposes 20(3), 207-226. https://doi.org/10.1016/S08894906(00)00012-0

Hyland, K., 2002, 'Authority and invisibility: Authorial identity in academic writing', Journal of Second Language Writing 34(8), 1091-1112. https://doi.org/10.1016/ s0378-2166(02)00035-8

Hyland, K., 2004, Genre and second language writing, The University of Michigan Press, Ann Arbor, MI.

Hyland, K., 2005a, Metadiscourse, Continuum, London.

Hyland, K., 2005b, 'Representing readers in writing: Student and expert practices', Linguistics and Education 16(4), 363-377. https://doi.org/10.1016/j.linged. 2006.05.002

Intaraprawat, P. \& Steffensen, M., 1995, 'The use of metadiscourse in good and poor ESL essays', Journal of Second Language Writing 4(3), 253-272. https://dol. org/10.1016/1060-3743(95)90012-8

Ivanic, R., 1998, Writing and identity: The discoursal construction of identity in academic writing, John Benjamins Publishing Company, Amsterdam.
Ivanic, R. \& Camps, D., 2001, 'I am how I sound voice as self -representation in L2 writing', Journal of Second Language Writing 10(1-2), 3-33. https://doi.org/10. 1016/S1060-3743(01)00034-0

Ivanic, R. \& Simpson, J., 1992, 'Who's who in academic writing?', in N. Fairclough (ed.), Critical language awareness, pp. 141-171, Longman, London.

Letsoela, P.M., 2013, 'Interacting with readers: Metadiscourse features in National University of Lesotho Undergraduate Students' Academic Writing', International Journal of Linguistics 5(6), 138. https://doi.org/10.5296/ijl.v5i6.4012

Li, T. \& Wharton, S., 2012, 'Metadiscourse repertoire of L1 Mandarin undergraduates writing in English: A cross-contextual, cross-disciplinary study', Journal of English forAcademic Purposes 11(4), 345-356. https://doi.org/10.1016/j.jeap.2012.07.004

Lillis, T., 1997, 'New voices in the academia? The regulative nature of academic writing conventions', Language and Education 11(3), 182-199. https://doi.org/10.1080/ 09500789708666727

Martinez, I.A., 2005, “"Native and non native writers” use of first person pronouns in the different sections of biology research articles in English', Journal of Second language Writing 14(3), 174-190. https://doi.org/10.1016/j.jslw.2005.06.001

Mur Duenas, P., 2010, 'Attitude markers in business management research articles: A cross cultural corpus-driven approach', International Journal of Applied Linguistics 20(1), 50-71. https://doi.org/10.1111/j.1473-4192.2009.00228.x

Read, B., Francis, B. \& Robson, J., 2001, “"Playing safe": Undergraduate essay writing and presentation of the student "voice"', British Journal of Sociology of Education 22(3), 387-399. https://doi.org/10.1080/01425690124289

Scott, M., 2008, Wordsmith tools version 5, Lexical Analysis Software Ltd, Liverpool.

Sheldon, E., 2009, 'From I to another: Discursive construction of self-representation in English and Castilian Spanish research articles', English for Specific Purposes 28(4), 251-265. https://doi.org/10.1016/j.esp.2009.05.001

Tang, R. \& John, S., 1999, 'The "I" in identity: Exploring writer identity in student academic writing through the first person pronoun', English for Specific Purposes 18(S1), S23-S39. https://doi.org/10.1016/S0889-4906(99)00009-5

Thompson, G., 2001, 'Interaction in academic writing: Learning to argue with the reader', Applied Linguistics 22(1), 58-78. https://doi.org/10.1093/applin/22.1.58

Thompson, G. \& Thetela, P., 1995, 'The sound of one clapping: The management of interaction in written discourse', Text 15(1), 103-127. https://doi.org/10.1515/ text.1.1995.15.1.103

Vande Kopple, W., 1985, 'Some exploratory discourse on metadiscourse', College Composition and Communication 36(1), 82-93. https://doi.org/10.2307/357609 


\section{Appendix 1}

\section{Assignment questions for Media Studies and Primary Education}

\section{Media Studies Department:}

\section{Course: BMS 302 - Gender, sex and ethnicity in media}

(1) Discuss the media treatment of one social group of your choice. What factors or contexts do you feel are relevant for understanding the ways in which this group is or has been represented?

(2) Do media images and messages only reflect the world, or do they also create it? Clearly they do both. But many studies demonstrate that media messages do not reflect the world as it really is. There are far more people of colour, disabled people, non-heterosexuals, seniors and poor people in the real world than we see on TV or in the movies. Media portrayal of women often leaves much to be desired, especially women in advertising. Discuss with reference to both print and broadcast media.

(3) 'Gender based restrictions on media representations in Africa constitute a form of neo-colonialism which are contrary to African cultural traditions'. Explain, with evidence, whether you agree or disagree with this quotation.

(4) What is now called 'globalization' would not be possible without mass media. Communication through modern technology has the potential to spread democracy. But corporate control of media production simultaneously threatens the ability of citizens to receive unbiased news to have their own messages heard. Discuss.

\section{Course: BMS 401-Imaging Africa}

(1) To what extent does the national museum of Botswana conform to stereotypes about Africa and to what extent does it provide an alternative Afro-centric view of Botswana?

(2) If an ancestral mask or a traditional foot stool is taken from its original context and function (e.g. to an art gallery) is its artistic value enhanced or diminished?

(3) In what ways do African artists or media practitioners provide a 'counter narrative' to colonial or neo colonial imaging of Africa with respect to disaster?

(4) 'Othering' is a natural human instinct. It only becomes dangerous when it is used for the purpose of 'social exclusion'. Debate this quotation by applying it to specific examples of Batswana imaging non-Batswana.

\section{Primary Education Department:}

Course: EPI 442 - Environmental education conservation strategies

(1) Discuss using elaborate examples, how indigenous knowledge can contribute towards sustainable use of the environment and its resources.

(2) Discuss how gender related activities contribute to natural resource depletion. In your discussion indicate how the environmental problems caused by such activities could be solved.

(3) Using examples in Botswana and elsewhere, how local communities can be an instrument in conserving the environment.

\section{Course: EPI 200 - Introduction to social studies}

Let's talk: primary schools pupils' views on the usefulness of Social Studies in making good citizens in Botswana. 